\title{
Catalytic cracking of light diesel over Au/ZSM-5 catalyst for increasing propylene production
}

\author{
Caixia Qi *, Yunxia Wang, Xiaotao Ding, Huijuan Su \\ Shandong Applied Research Center of Gold Nanotechnology (Au-SDARC), School of Chemistry and Chemical Engineering, Yantai University, Yantai \\ 264005, Shandong, China
}

\section{A R T I C L E I N F O}

Article history:

Received17 May 2016

Accepted 28 June 2016

Published 5 October 2016

\section{Keywords:}

Fluid catalytic cracking

ZSM-5

Gold modification

Propylene selectivity

Micro-activity test

\begin{abstract}
A B S T R A C T
The catalytic cracking of light diesel oil $\left(235-337^{\circ} \mathrm{C}\right)$ over gold-modified ZSM-5 was investigated in a small confined fluidized bed at $460{ }^{\circ} \mathrm{C}$ and ambient pressure. Different Au/ZSM-5 catalysts were prepared by a modified deposition-precipitation method by changing the preparation procedure and the amount of gold loading and were characterized by X-ray diffraction, $\mathrm{N}_{2}$ adsorption-desorption, temperature-programmed desorption of $\mathrm{NH}_{3}$, transmission electron microscopy and inductively coupled plasma spectrometer. It was found that a small amount of gold had a positive effect on the catalytic cracking of light diesel oil and increased propylene production at a relatively low temperature. The maintenance of the ZSM-5 MFI structure, pore size distribution and the density of weak and strong acid sites of the Au/ZSM- 5 catalysts depended on the preparation parameters and the Au loading. Simultaneous enhancement of the micro-activity and propylene production relies on a synergy between the pore size distribution and the relative intensity of the weak and strong acid sites. A significant improvement in the micro-activity index with an increase of 4.5 units and in the propylene selectivity with an increase of 23.2 units was obtained over the $\mathrm{Au} / \mathrm{ZSM}-5$ catalyst with an actual Au loading of $0.17 \mathrm{wt} \%$.
\end{abstract}

(C) 2016, Dalian Institute of Chemical Physics, Chinese Academy of Sciences. Published by Elsevier B.V. All rights reserved.

\section{Introduction}

In recent decades, and especially in the last 10 years, gold catalysts have become a vital new force in the field of green chemistry [1] owing to the explosive growth of research and development in the fields of pollution control, fine chemical synthesis and energy. From simple reactions, such as CO oxidation and epoxidation of propylene [2,3], the studied reaction systems have been extended to hydrogenation, carbonylation, condensation and other kinds of reactions in organic synthesis [4-6]. The research category has expanded from heterogeneous catalysis [7] to homogeneous catalysis [8] and photocataly- sis [9]. Studies of many different reaction systems over Au catalysts have shown that compared with other precious metals, $\mathrm{Au}$ catalysts were characterized by some particular features, such as a relatively high catalytic activity at low temperature $[2,4]$, high selectivity of the target product [3-6] and a simple route for the green synthesis of chemicals [4-6]. However, most of the studied reactions have been performed under mild reaction conditions; the investigation of gold catalysts in relatively harsh catalytic reaction systems, such as catalytic cracking of heavy oil at temperatures higher than $400{ }^{\circ} \mathrm{C}$ with numerous reactants, has rarely been reported.

Propylene, as an important organic synthetic raw material,

\footnotetext{
* Corresponding author. Tel/Fax: +86-535-6911732; E-mail: qicx@ytu.edu.cn

This work was supported by the Shandong Taishan Scholarship, the Yantai double-hundreds talents plan, and the Shandong Natural Science Foundation (ZR2015BM006).

DOI: 10.1016/S1872-2067(16)62499-3 | http://www.sciencedirect.com/science/journal/18722067 | Chin. J. Catal., Vol. 37, No. 10, October 2016
} 
can be used to produce polypropylene, acrylonitrile, propylene oxide, isopropyl benzene, isopropyl alcohol and other industrial raw materials. The consumption of propylene worldwide has increased dramatically owing to market demands for the downstream derivatives (mainly polypropylene). The rate at which the consumption of propylene has grown in recent years is faster than that of ethylene. Propylene is mostly produced by steam cracking and fluidized catalytic cracking (FCC) as well as dehydrogenation of propane. Because of lower power consumption, cheaper materials and adaptable devices, the FCC process has played an increasingly important role in the production of propylene, whereas the ratio of propylene made from steam cracking has gradually decreased [10-12]. The propylene yield obtained with the FCC process can be increased significantly by using high quality raw materials, novel selective catalysts/additives and by optimizing the process [13].

ZSM-5 are the most widely used active components in catalytic cracking catalysts to increase the propylene selectivity owing to their special pore structure with shape selectivity, strong acidity, low hydrogen transfer activity and hydrothermal stability $[10,11,14]$. The modification of ZSM-5 is one of the main methods used to develop more active catalysts and increase the propylene yield. To further increase the accessibility of the active sites of ZSM-5, the study on nanometer ZSM-5 $[15,16]$, single [17] or meso- and microporous composite ZSM-5 [18], and mesoporous ZSM-5 [19] has attracted attention. However, the major method for modification of ZSM-5 is through the addition of different elements including electronegative elements such as $\mathrm{P}$ and $\mathrm{B}$, alkali and alkaline earth elements such as $\mathrm{Mg}, \mathrm{Ca}, \mathrm{Ba}, \mathrm{K}$ and $\mathrm{Na}$, other rare earth elements such as $\mathrm{La}$ and $\mathrm{Ce}$, and transition metal elements such as $\mathrm{Cu}, \mathrm{W}, \mathrm{Pt}, \mathrm{Fe}$ and Ti $[17,20]$.

The modified ZSM-5 that is currently available has been effective for the production of propylene by catalytic cracking of $\mathrm{C}_{4}$ hydrocarbons and pyrolysis of naphtha and as an additive in the FCC process. However, the working temperatures are relatively high $\left(>510^{\circ} \mathrm{C}\right)$ and the capability to produce propylene is greatly reduced if the reaction temperature is reduced $[10,14,17,19,21,22]$. Nanoparticles, clusters and complexes of gold have widely been used to catalyze different types of reactions and have significant catalytic activity under mild reaction conditions [2-9]. Can gold be used to reduce the reaction temperature of FCC and maintain the propylene yield?

Incipient wetness impregnation [23], ion exchange [24,25], chemical vapor deposition [26] and deposition precipitation (DP) [27] have been used to deposit gold into ZSM-5. Good thermal stability of $\mathrm{Au} / \mathrm{ZSM}-5$ catalyst at temperatures as high as $800{ }^{\circ} \mathrm{C}$ has also been reported [28], indicating the possible application of Au/ZSM-5 in the FCC process. In the present study, Au/ZSM-5 catalyst samples were prepared using a modified DP method described previously [29,30]. We investigated their selectivity for the synthesis of propylene and the micro-activity index in the catalytic cracking of light diesel oil $\left(235-337{ }^{\circ} \mathrm{C}\right)$ at a relatively low temperature of $460{ }^{\circ} \mathrm{C}$. The modification of ZSM- 5 by a small amount of gold had a positive effect on the production of propylene and maintained or even enhanced the micro-activity.

\section{Experimental}

\subsection{Catalyst preparation}

The received ZSM-5 zeolite $(\mathrm{Si} / \mathrm{Al}=35$, surface area 281.9 $\mathrm{m}^{2} / \mathrm{g}$ ) was calcined at $540{ }^{\circ} \mathrm{C}$ in air for $2 \mathrm{~h}$ prior to further application.

First, to investigate the impact of the preparation parameters, four Au/ZSM-5 catalysts, denoted as Au/ZSM-5-a, $\mathrm{Au} / \mathrm{ZSM}-5-\mathrm{b}, \mathrm{Au} / \mathrm{ZSM}-5-\mathrm{c}$ and Au/ZSM-5-d, were prepared by using our modified DP method described previously $[29,30]$. Briefly, ZSM-5 was first impregnated using a given concentration of $\mathrm{HAuCl}_{4}$ solution at $\mathrm{pH}=9$, which was adjusted using a $\mathrm{KOH}$ solution. The nominal Au loading was $1.0 \mathrm{wt} \%$. $\mathrm{Au} / \mathrm{ZSM}-5$-a was obtained by reducing the impregnated precursor in-situ using $\mathrm{NaBH}_{4}$. Au/ZSM-5-b was obtained by soaking the impregnated precursor in an ammonia solution at $\mathrm{pH}=10$ for $24 \mathrm{~h}$, washing three times followed by reduction in situ using $\mathrm{NaBH}_{4}$. Au/ZSM-5-c was obtained by only drying the impregnated precursor at $110{ }^{\circ} \mathrm{C}$ for $2 \mathrm{~h}$. Au/ZSM-5-d was obtained by soaking the impregnated precursor in an ammonia solution at $\mathrm{pH}=10$ for $24 \mathrm{~h}$ followed by filtration and washing three times with water, as reported previously [29,30]. All four catalysts precursors were calcined at $300^{\circ} \mathrm{C}$ for $2 \mathrm{~h}$.

Secondly, to investigate the impact of $\mathrm{Au}$ loading, the $\mathrm{Au} / \mathrm{ZSM}-5-\mathrm{d}$ catalysts with theoretical Au contents of 0.5, 0.8, 1.2 and $1.5 \mathrm{wt} \%$ except for $1.0 \mathrm{wt} \%$ were also prepared by above described procedure. The obtained catalysts were designated as $x \% \mathrm{Au} / \mathrm{ZSM}-5-\mathrm{d}$, in which $x \%$ is the nominal quantity percentage of $\mathrm{Au}$.

Because the micro-activity of fresh FCC catalysts is high and unstable, which would not reflect the real situation in a practical application, hydrothermal treatment is usually adopted prior to micro-activity testing to deactivate the fresh catalyst. Therefore, all the samples including the parent ZSM-5 were aged at $800{ }^{\circ} \mathrm{C}$ in flowing water steam for $4 \mathrm{~h}$ and then calcined at $300{ }^{\circ} \mathrm{C}$ for $1 \mathrm{~h}$.

\subsection{Characterization}

A Shimadzu XRD-6100 diffractometer using $\mathrm{Cu} K_{\alpha}$ radiation ( $40 \mathrm{kV}, 30 \mathrm{~mA}$ ) was employed to obtain X-ray diffraction (XRD) patterns of all studied samples with a scanning range of $2 \theta$ from 10 to $80^{\circ}$ at a scanning rate of $6^{\circ} / \mathrm{min}$. A NOVA-3000E (Quantachrome Corp.) was used to obtain $\mathrm{N}_{2}$ adsorption-desorption isotherms at $-196{ }^{\circ} \mathrm{C}$. Prior to analysis, each sample was evacuated at $120^{\circ} \mathrm{C}$ for $4 \mathrm{~h}$.

A Tp-5080 multi-functional automatic adsorption instrument (Tianjin Xianquan Industry and Trade Development Co., LTD, Tianjin, China) was used to take temperature-programmed desorption of $\mathrm{NH}_{3}\left(\mathrm{NH}_{3}-\mathrm{TPD}\right)$ curves for all studied catalysts. The sample was loaded into a stainless U-shaped microreactor and pretreated at $600{ }^{\circ} \mathrm{C}$ in flowing He stream $(20$ $\mathrm{mL} / \mathrm{min}$ ) for $0.5 \mathrm{~h}$ before it was saturated with $\mathrm{NH}_{3}$ gas at low temperature. 
A transmission electron microscope (TEM, JEOL JEM-2100, JEOL Company, Tokyo, Japan) equipped with an Oxford INCA spectrometer for X-ray energy dispersive (EDX) spectroscopy analysis was used at $200 \mathrm{kV}$ accelerating voltage to evaluate the dispersion properties of two representative Au/ZSM-5 samples.

An IRIS IIXSP inductively coupled plasma spectrometer (ICP-AES, Thermo Electron Corporation, USA) was used to measure the quantity of gold in the samples at working conditions of $27 \mathrm{MHz}$ and $112 \mathrm{~kW}$. A hydrofluoric acid solution and aqua regia were used to dissolve the samples.

\subsection{Micro-activity test}

Micro-activity tests of the catalysts were obtained using Dagang light diesel $\left(235-337^{\circ} \mathrm{C}\right)$ as the feedstock in a small confined fluidized bed at $460{ }^{\circ} \mathrm{C}$. Three grams of catalyst was placed into a self-constructed reaction device (Fig. 1) and the oil was injected into the furnace by a syringe when the temperature reached a preset temperature. The weight ratio of the catalyst to oil and the contact time were 3.2 and $70 \mathrm{~s}$, respectively. The products were purged by using high-purity nitrogen after the completion of the feed and separated through an ice-water bath.

The gaseous products were determined by an on-line GC-920X with a flame ionization detector equipped with an OV-101 capillary column. The liquid products were analyzed by manual sampling after collection in a glass container. The composition of gasoline and diesel in the liquid phase was determined at the retention time of $n$-dodecane (Fig. 2).

The area normalization method was applied to collect the data. Propylene selectivity was defined by the content of propylene in the gaseous products. The micro-activity index (MAT) and conversion of the oil were calculated according to the RIPP92-90 method using equations (1) and (2):

$$
\text { MAT }=100-100 \times(1-G \%) \times W_{1} / W
$$

Conversion $=\left(W \times D_{0} \%-D \% \times W_{1}\right) / W \times D_{0} \%$

where $D_{0} \%$ refers to the proportion of diesel components in the

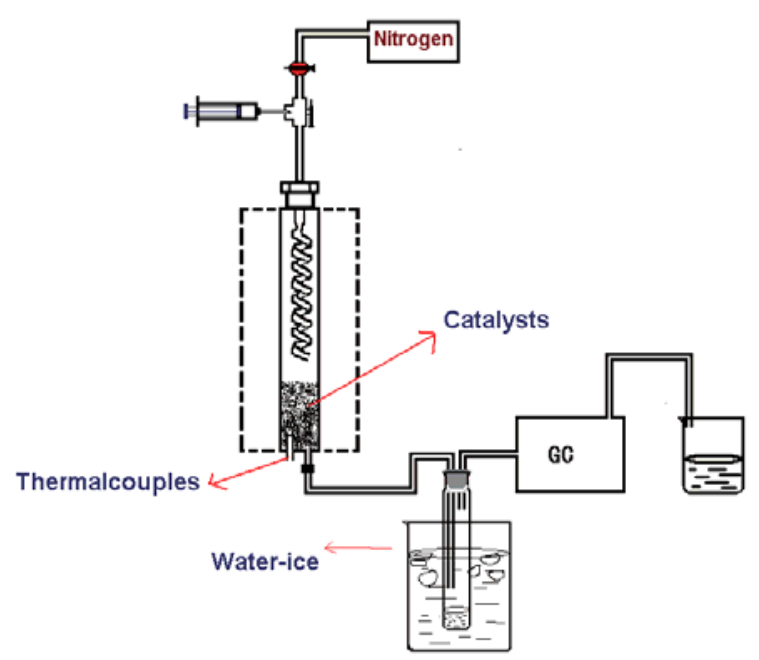

Fig. 1. Schematic diagram of the micro-activity measurement.

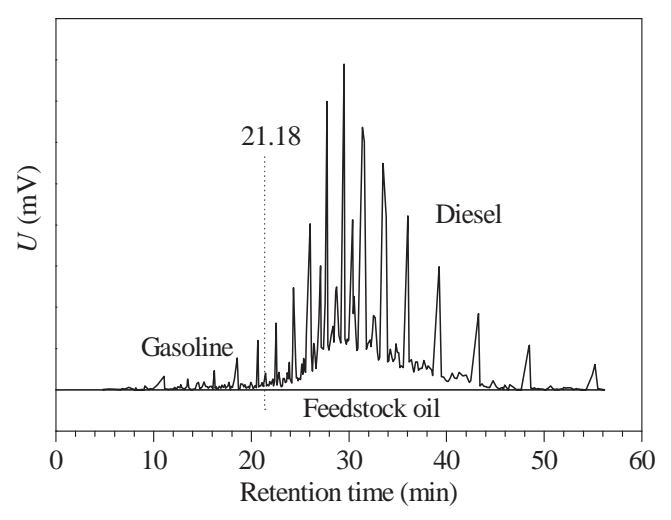

Fig. 2. Cut-off point of the gasoline and diesel in the feed oil.

light diesel oil feed with hydrocarbons heavier than $n$-dodecane; $W$ and $W_{1}$ refer to the quality of the liquids before and after reaction; $D \%$ and $G \%$ refer to relative content of diesel and gasoline, respectively, in the liquid product. At least, two tests were performed to evaluate the catalysts and the mean values were taken with the absolute difference between the two parallel results less than $2 \%$.

\section{Results and discussion}

\subsection{The catalytic cracking results of light diesel oil}

The results of the catalytic cracking of light diesel over ZSM-5 with or without gold modification are listed in Table 1, including the actual Au loading and the ratio of weak acid sites to strong acid sites, which were based on our $\mathrm{NH}_{3}$-TPD measurements. In comparison with the parent ZSM-5 catalyst, it is clear that the introduction of gold into ZSM-5 improved the propylene selectivity with the exception of the Au/ZSM-5-a catalyst. However, the catalytic cracking activity represented by a micro-activity index was only enhanced over the three catalysts of Au/ZSM-5-d with theoretical Au loadings of 0.5, 0.8 and $1.0 \mathrm{wt} \%$. The corresponding increase in propylene selectivity over these three catalysts was $8.8 \%, 2.9 \%$ and $23.2 \%$, whereas the increase in their micro-activity index (MAT) was $7.1 \%$, $4.3 \%$ and $4.5 \%$, respectively. The results suggest that a small amount of gold has a positive effect on the catalytic cracking of light diesel oil to increase the production of propylene at a lower reaction temperature of $460^{\circ} \mathrm{C}$.

Recently, Guo et al. [31,32] found that a series of Si/Al molecular sieves deposited with gold showed higher activity and a lower reaction temperature than those without gold modification for aromatization, isomerization and alkylation reactions and catalytic cracking of $\mathrm{C}_{3}-\mathrm{C}_{9}$ hydrocarbons. This further supports the potential application of gold in the field of petroleum chemistry.

\subsection{XRD measurements}

Fig. 3 shows the XRD patterns of ZSM-5 and the Au/ZSM-5 catalysts. In comparison with the parent ZSM-5, the patterns of $\mathrm{Au} / \mathrm{ZSM}-5-\mathrm{b}, \mathrm{c}$, and d seem to maintain the same structure, but 
Table 1

Product distributions of the catalytic cracking of light diesel oil at $460{ }^{\circ} \mathrm{C}$ over the studied catalysts.

\begin{tabular}{|c|c|c|c|c|c|c|c|c|}
\hline \multirow{2}{*}{ Catalyst } & \multicolumn{3}{|c|}{ Product distribution (\%) } & \multirow{2}{*}{$\begin{array}{c}\text { Conversion } \\
(\%)\end{array}$} & \multirow{2}{*}{$\begin{array}{l}\text { MAT } \\
(\%)\end{array}$} & \multirow{2}{*}{$\begin{array}{c}\text { Propylene selectivity } \\
(\%)\end{array}$} & \multirow{2}{*}{$\begin{array}{l}\mathrm{Au}_{\text {cont. }}{ }^{\mathrm{b}} \\
(\mathrm{wt} \%)\end{array}$} & \multirow{2}{*}{$\mathrm{W} / \mathrm{S}$} \\
\hline & Dry gas $+\mathrm{LPG}^{\text {a }}$ & Gasoline & Diesel oil & & & & & \\
\hline ZSM-5 & 40.4 & 8.6 & 51.0 & 46.0 & 49.0 & 29.6 & - & 4.6 \\
\hline $1.0 \mathrm{wt} \% \mathrm{Au} / \mathrm{ZSM}-5-\mathrm{a}$ & 33.7 & 10.0 & 56.3 & 28.1 & 32.1 & 27.9 & 0.67 & 0 \\
\hline $1.0 \mathrm{wt} \% \mathrm{Au} / \mathrm{ZSM}-5-\mathrm{b}$ & 26.7 & 4.9 & 68.4 & 40.4 & 43.8 & 31.4 & 0.08 & 22.5 \\
\hline $1.0 \mathrm{wt} \% \mathrm{Au} / \mathrm{ZSM}-5-\mathrm{c}$ & 33.7 & 4.7 & 61.6 & 34.1 & 38.3 & 40.8 & 0.91 & 2.3 \\
\hline 0.5 wt $\% \mathrm{Au} / \mathrm{ZSM}-5-\mathrm{d}$ & 55.8 & 3.1 & 41.1 & 67.1 & 56.1 & 38.4 & 0.10 & 3.4 \\
\hline 0.8 wt $\% \mathrm{Au} / \mathrm{ZSM}-5-\mathrm{d}$ & 44.9 & 8.4 & 46.7 & 50.1 & 53.3 & 32.5 & 0.12 & 3.35 \\
\hline $1.0 \mathrm{wt} \% \mathrm{Au} / \mathrm{ZSM}-5-\mathrm{d}$ & 46.7 & 6.8 & 46.5 & 50.4 & 53.5 & 52.8 & 0.17 & 3.8 \\
\hline $1.2 \mathrm{wt} \% \mathrm{Au} / \mathrm{ZSM}-5-\mathrm{d}$ & 24.2 & 11.1 & 64.7 & 30.9 & 35.3 & 41.4 & 0.20 & 4.07 \\
\hline $1.5 \mathrm{wt} \% \mathrm{Au} / \mathrm{ZSM}-5-\mathrm{d}$ & 23.9 & 10.2 & 65.9 & 29.6 & 34.1 & 68.6 & 0.21 & 4.5 \\
\hline
\end{tabular}

${ }^{a}$ LPG means liquefied petroleum gas. ${ }^{b}$ The actual Au loading measured by ICP-AES analysis. ${ }^{c}$ The ratio of weak acid to strong acid based on NH -TPD measurements.

the intensity decreases gradually from $\mathrm{Au} / \mathrm{ZSM}-5-\mathrm{d}$ to $\mathrm{Au} / \mathrm{ZSM}$-5-c and then Au/ZSM-5-b. Conversely, Au-ZSM-a completely loses the structure of the original pattern. The $\mathrm{Au} / \mathrm{ZSM}-5$-d sample exhibits the typical peaks of ZSM-5 with similar intensities, indicating that the structure remains intact after the modification. The XRD patterns of Au/ZSM-5-d with various Au loadings of $0.5 \%-1.5 \%$ (not shown) further support the maintenance of the ZSM-5 structure through the d-type preparation procedure.

For all samples with gold modification, the characteristic peaks corresponding to $\mathrm{Au}(111)$ and (200) crystal planes are detected at $2 \theta=38.2^{\circ}$ and $44.4^{\circ}$, which means that the Au particles are not as small as those that we previously prepared over an alumina support [29,30]. The mean size of the Au particles on alumina was in the range of 2-3 nm. The diameters of the $\mathrm{Au}$ particles estimated by the Scherer formula are approximately $20 \mathrm{~nm}$. This value is quite rough because the intensities of $\mathrm{Au}$ peaks are not very visible and vary with different samples.

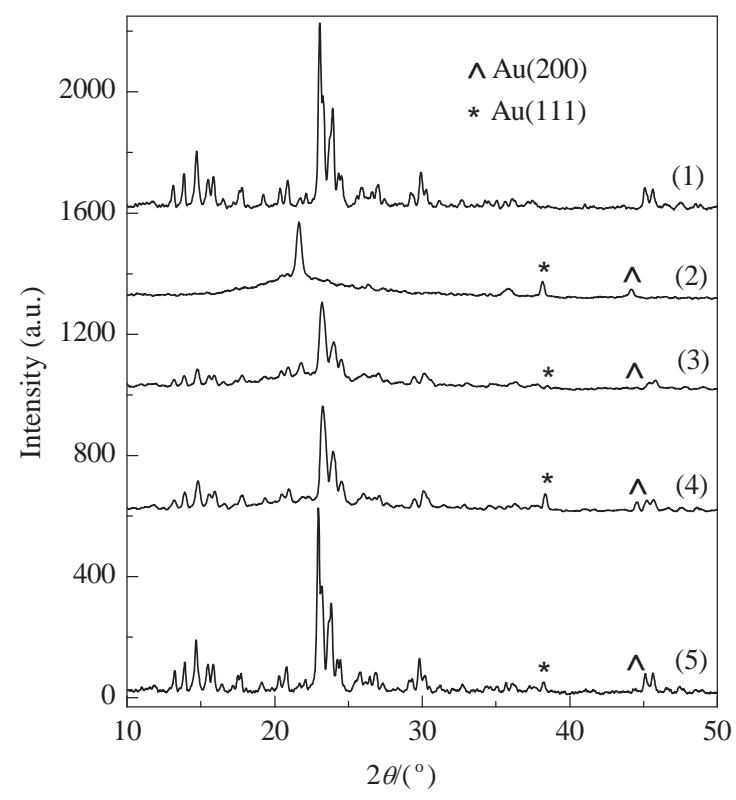

Fig. 3. XRD patterns of ZSM-5 (1), Au/ZSM-5-a (2), Au/ZSM-5-b (3), $\mathrm{Au} / \mathrm{ZSM}-5-\mathrm{c}(4)$, and Au/ZSM-5-d (5) catalysts.

\subsection{TEM observations}

To investigate the dispersion of gold particles in the ZSM-5, two samples of 0.5 and $1.5 \mathrm{wt} \% \mathrm{Au} / \mathrm{ZSM}-5-\mathrm{d}$ were selected to make TEM observations. The representative TEM images of the 1.5 wt $\%$ Au/ZSM-5-d sample are displayed in Fig. 4. The size distribution of the $\mathrm{Au}$ particles varied in a rather large range from $<10$ to $<200 \mathrm{~nm}$ regardless of the Au loadings. The deposition of $\mathrm{Au}$ particles was very inhomogeneous, with a few $\mathrm{Au}$ particles on some parts of the ZSM-5 substrate whereas on other parts tacking numbers of Au particles. A few small $\mathrm{Au}$ particles, which are not easy to distinguish, are indicated by red arrows in the images.

From these randomly dispersed Au particles, we can see that some Au particles form a flat shape and show a stronger interaction with the substrate. Furthermore, some smaller $\mathrm{Au}$ particles may be embedded in slit-pores between the flaky ZSM-5 particles. Clearer images of this are displayed in Fig. 5, which shows two TEM images of $1.5 \mathrm{wt} \%$ Au/ZSM-5-d before and after it is aged in steam at $800{ }^{\circ} \mathrm{C}$. These cases are surely not popular for the studied samples with gold modification; however, it may account for the contribution of these small $\mathrm{Au}$ particles on the pore size distribution of the parent ZSM-5 sub-

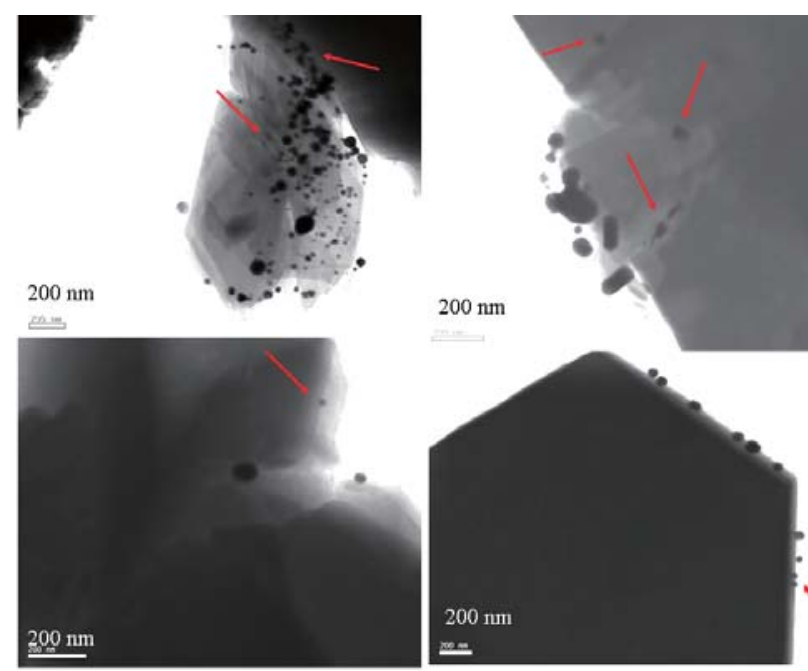

Fig. 4. Representative TEM images of $1.5 \mathrm{wt} \% \mathrm{Au} / \mathrm{ZSM}-5-\mathrm{d}$ sample. 

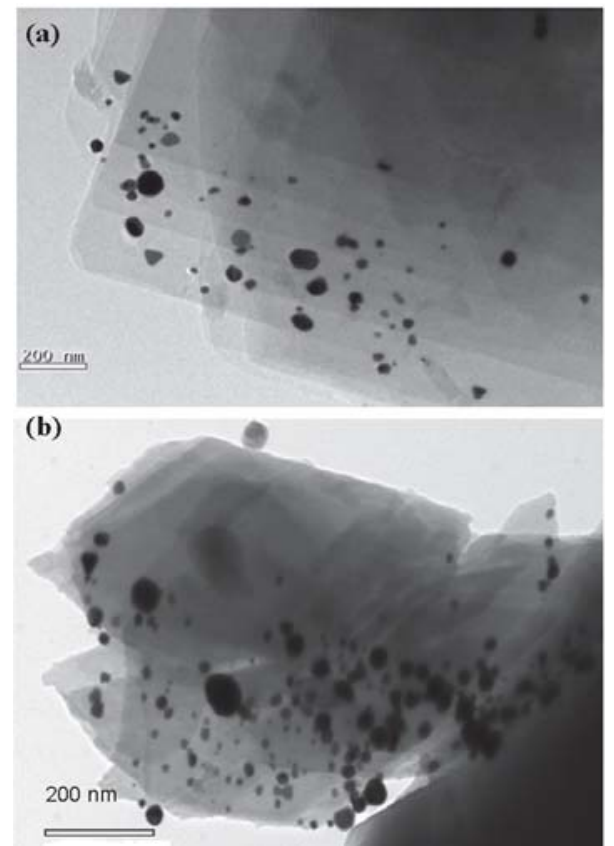

Fig. 5. TEM images of $1.5 \mathrm{wt} \% \mathrm{Au} / \mathrm{ZSM}-5$ before (a) and after (b) aged in steam at $800^{\circ} \mathrm{C}$.

strate and hence exert some impact on the catalytic cracking performance.

\section{4. $N_{2}$ adsorption-desorption isotherms of ZSM-5 with and without gold modification}

Fig. 6 shows the $\mathrm{N}_{2}$ adsorption-desorption isotherms of ZSM-5 and the Au/ZSM-5-a, b, c, d catalysts. The isotherms of ZSM-5 and Au/ZSM-5-c and Au/ZSM-5-d present a type I isotherm with a $\mathrm{H}_{4}$ hysteresis loop, which is typical for microporous materials with some slit-like pores and mesopores. The capillary condensation phenomenon at lower relative pressure range of $0.2-0.3$ for the sample of Au/ZSM-5-c indicates the presence some disordered pores. The corresponding pore size distributions confirmed that the majority of these
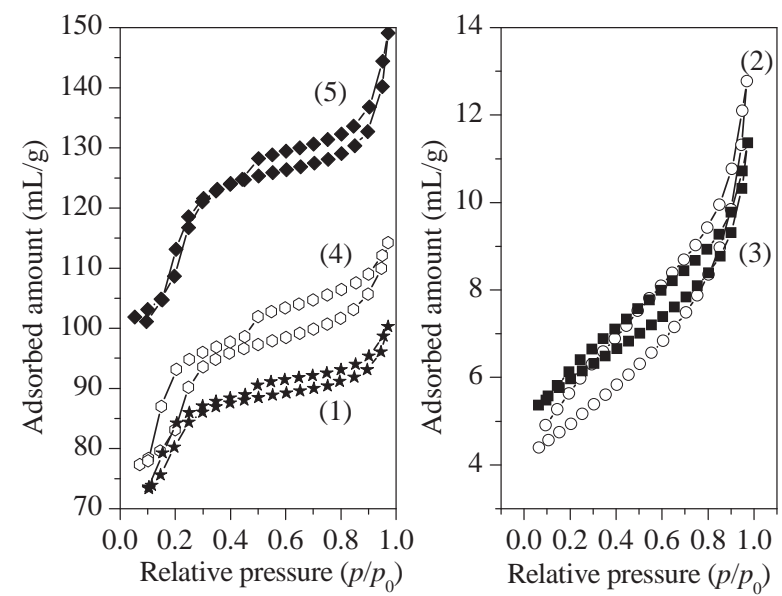

Fig. 6. $\mathrm{N}_{2}$ adsorption-desorption isotherms of ZSM-5 (1) and Au/ZSM-5-a (2), Au/ZSM-5-b (3), Au/ZSM-5-c (4) and Au/ZSM-5-d (5) catalysts. pores were approximately $2 \mathrm{~nm}$, as shown in Fig. 7 for the pore size distributions of ZSM-5 and $1.0 \mathrm{wt} \% \mathrm{Au} / \mathrm{ZSM}-5-\mathrm{d}$ as well as other samples.

Conversely, the adsorbed amount of liquid nitrogen on $\mathrm{Au} / \mathrm{ZSM}-5-\mathrm{a}$ and $\mathrm{Au} / \mathrm{ZSM}-5-\mathrm{b}$ is quite low, showing a type III isotherm with a $\mathrm{H}_{3}$ hysteresis loop. These are nonporous materials that have larger slit-like pores among stacked flaky particles. The XRD patterns indicate that Au/ZSM-5-a and $\mathrm{Au} / \mathrm{ZSM}-5-\mathrm{b}$ almost lose the original MFI structure of the ZSM-5. This may explain their lower selectivity for propylene production, as shown in Table 1.

$\mathrm{N}_{2}$ adsorption-desorption isotherms and pore size distribution curves of ZSM-5 and five Au/ZSM-5-d samples with various Au loadings are displayed in Fig. 7. Similar to that of the parent ZSM-5, the isotherms of all the samples containing $\mathrm{Au}$ are typical type I isotherms with a $\mathrm{H}_{4}$ hysteresis loop, which means that these microporous materials have a combination of some slit-like pores and mesopores. The difference between them is reflected, to some extent, in their pore size distribution curves. The Au/ZSM-5-d sample with $0.5 \mathrm{wt} \%$ nominal $\mathrm{Au}$ loading showed the narrowest pore size distribution, followed by the sample with $1.0 \mathrm{wt} \%$ Au loading. The sample with 0.8 wt $\%$ Au showed a similar pore size distribution range to that of the parent ZSM-5, slightly wider than the sample with $1.0 \mathrm{wt} \%$ $\mathrm{Au}$ and narrower than the sample with $1.2 \mathrm{wt} \% \mathrm{Au}$. The sample with $1.5 \mathrm{wt} \% \mathrm{Au}$ had the widest pore size distribution. The width of the pore size distribution could be sorted as follows: The sample with $1.5 \mathrm{wt} \% \mathrm{Au}>>$ the sample with $1.2 \mathrm{wt} \% \mathrm{Au}>$ the parent $\mathrm{ZSM}-5 \approx$ the sample with $0.8 \mathrm{wt} \% \mathrm{Au}>$ the sample

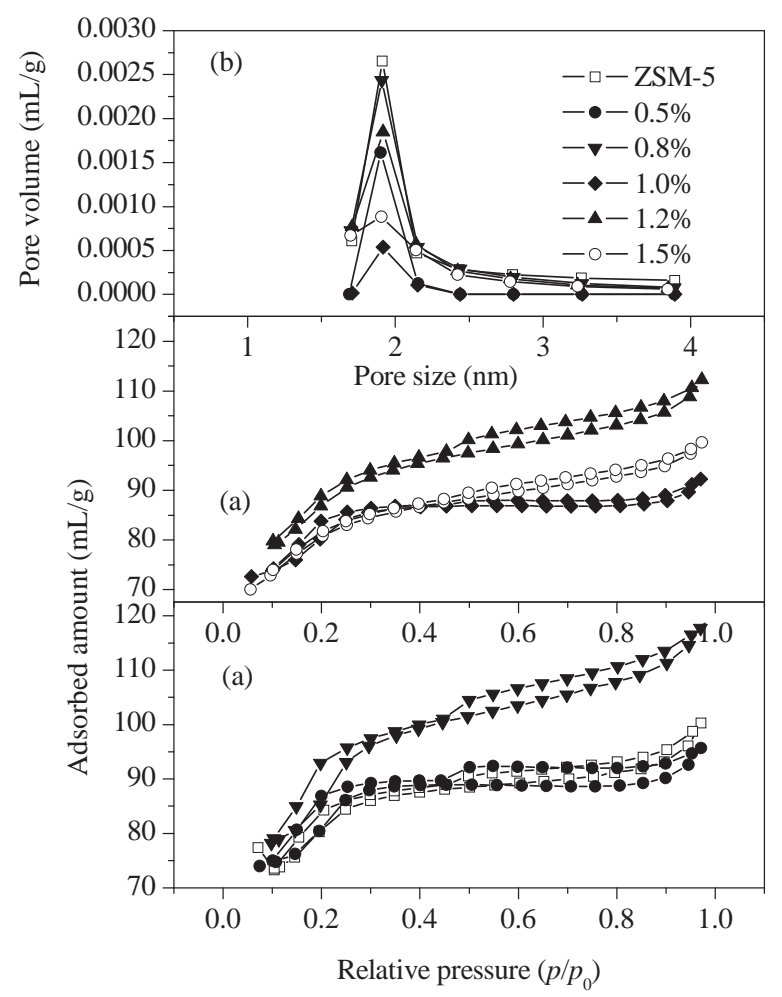

Fig. 7. $\mathrm{N}_{2}$ adsorption-desorption isotherms (a) and pore size distribution curves (b) of ZSM-5 and five Au/ZSM-5-d samples with different $\mathrm{Au}$ loadings. 
with $1.0 \mathrm{wt} \% \mathrm{Au}>$ the sample with $0.5 \mathrm{wt} \% \mathrm{Au}$. Notably, the three samples that have a narrower pore size distribution than the parent ZSM-5 show an enhancement in both propylene selectivity and micro-activity.

\section{5. $\mathrm{NH}_{3}-\mathrm{TPD}$ measurements}

The acid sites of zeolites are often characterized by $\mathrm{NH}_{3}$-TPD. In general, there are two well resolved peaks for zeolites, which are referred to as the low temperature (LT) peak and the high temperature (HT) peak, corresponding to the total number of weak acid sites and strong acid sites, respectively. The strong acid sites contribute to the decomposition of $\mathrm{NH}_{4}{ }^{+}$ ions formed over strong Brønsted acid sites. As shown in Fig. 8, one clear LT peak and one small HT peak are observed. Except for $\mathrm{Au} / \mathrm{ZSM}-5-\mathrm{a}$ and $\mathrm{Au} / \mathrm{ZSM}-5-\mathrm{b}$ in which the structure is destroyed, the Au modification dramatically increases the total acid density, and especially a significant increase in the weak acid intensity with an increase in gold loading. This could be correlated to the increase in selectivity for the synthesis of propylene. However, only the three catalysts $0.5,0.8$ and 1.0 $w t \%$ Au/ZSM-5-d exhibited good performance in both propylene selectivity and micro-activity index, as shown in Table 1. It has been reported that relatively mild acidity strength and a reasonable number of strong acid sites favor propylene production [33]. Taking into account the pore size distribution, the ratio of weak acid sites to strong acid sites calculated from the $\mathrm{NH}_{3}$-TPD curves (Table 1) suggests that there is a synergy between the acid property and pore selectivity in propylene production. There are no big differences in the ratio of weak to strong acid sites for the catalysts that maintain the ZSM-5 structure.

\subsection{Discussion}

In general, some $\mathrm{SiO}_{2}$ and $\mathrm{Al}_{2} \mathrm{O}_{3}$ in the zeolite can be dissolved in a basic solution, leading to the loss of the strong acid sites and the partial destruction of the structure. A weak base could dissolve a small amount of silica and alumina, forming some mesopores by extending the micropores. A strong base could destroy the crystal structure of the molecular sieve and turn the molecular sieve into an amorphous non-acidic material with big holes [34]. The destruction of the structure of $\mathrm{Au} / \mathrm{ZSM}-5-\mathrm{a}$ and $\mathrm{Au} / \mathrm{ZSM}-5-\mathrm{b}$ is possibly related to the use of $\mathrm{NaBH}_{4}$ in the preparation procedure, which is in agreement with the results in Ref. [35].

In this study, a KOH solution was used to adjust the $\mathrm{pH}$ of a $\mathrm{HAuCl}_{4}$ solution to 9 and then the dried precursor was soaked in ammonia solution at $\mathrm{pH}=10$ for $24 \mathrm{~h}$ before the final step to

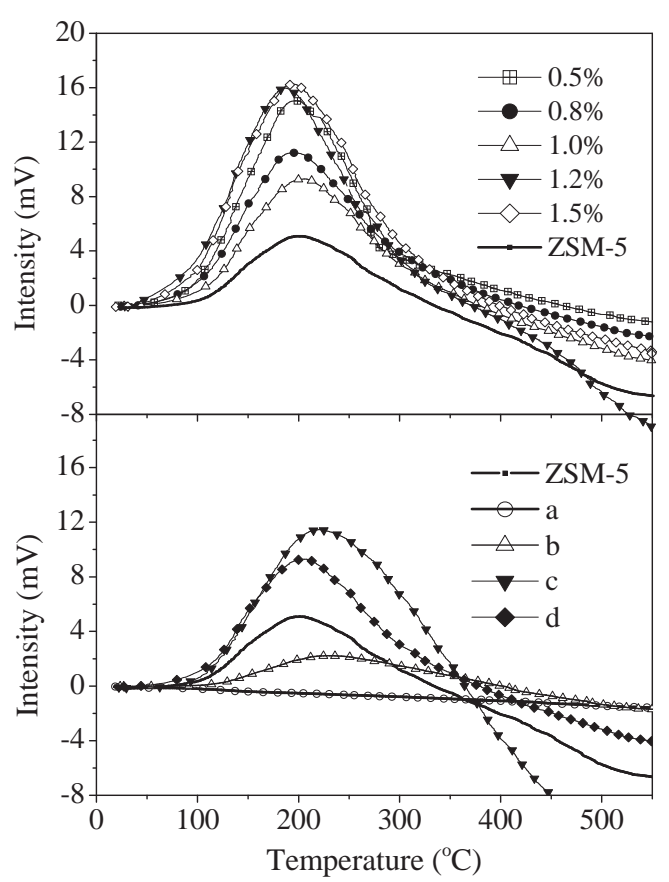

Fig. 8. $\mathrm{NH}_{3}$-TPD curves of the parent ZSM-5 and all the samples of $\mathrm{Au}$ modified ZSM-5.

prepare five $\mathrm{Au} / \mathrm{ZSM}-5$ - $\mathrm{d}$ catalysts with nominal Au loadings of $0.5,0.8,1.0,1.2$ and $1.5 \mathrm{wt} \%$. To evaluate the influence of the two bases used in the preparation of the catalyst on the catalytic cracking reaction, two new samples were prepared without introducing gold and tested under the same reaction conditions. The first sample was prepared by replacing the $\mathrm{HAuCl}_{4}$ solution with a $\mathrm{HCl}$ solution (same amount of $\mathrm{Cl}^{-}$) and adjusting the $\mathrm{pH}$ of the $\mathrm{HCl}$ solution to 9 by using a $\mathrm{KOH}$ solution before the impregnation of the parent ZSM-5. The dried precursor was then soaked in ammonia solution $(\mathrm{pH}=10)$ for $24 \mathrm{~h}$ followed by washing, drying and calcination. The second sample was directly soaked in the parent ZSM-5 in an ammonia solution $(\mathrm{pH}=10)$ for $24 \mathrm{~h}$ and then washed, dried and calcined. The catalytic cracking testing results at $460{ }^{\circ} \mathrm{C}$ together with the corresponding results on the parent ZSM-5 performed at the same time are shown in Table 2. The parent ZSM-5 used here was from another batch, which was purchased from the same company and had the same $\mathrm{Si} / \mathrm{Al}$ ratio and a similar surface area to the one in Table 1. Small differences in testing results can be found over two parents of ZSM-5.

It is clear that similar propylene selectivity and micro-activity are obtained for the two base-treated samples, with an increase in the propylene selectivity and a decrease in the micro-activity in comparison with those of the parent ZSM-5.

Table 2

The catalytic cracking results over ZSM- 5 treated by bases.

\begin{tabular}{|c|c|c|c|c|c|c|}
\hline \multirow{2}{*}{ Catalyst } & \multicolumn{3}{|c|}{ Product distribution (\%) } & \multirow{2}{*}{$\begin{array}{c}\text { Conversion } \\
(\%)\end{array}$} & \multirow{2}{*}{$\begin{array}{l}\text { MAT } \\
(\%)\end{array}$} & \multirow{2}{*}{$\begin{array}{c}\text { Propylene selectivity } \\
(\%)\end{array}$} \\
\hline & Dry gas $+\mathrm{LPG}^{\mathrm{a}}$ & Gasoline & Diesel oil & & & \\
\hline ZSM-5 & 44.0 & 6.2 & 49.8 & 47.6 & 50.3 & 31.4 \\
\hline ZSM-5 treated by bases (1) & 35.5 & 6.6 & 57.9 & 39.1 & 42.2 & 48.2 \\
\hline ZSM- 5 treated by bases (2) & 37.7 & 6.0 & 56.3 & 40.7 & 43.7 & 49.5 \\
\hline
\end{tabular}


This implies that any difference in the amounts of residual $\mathrm{K}$ and $\mathrm{Cl}$ in the five $\mathrm{Au} / \mathrm{ZSM}-5-\mathrm{d}$ catalysts with various $\mathrm{Au}$ loadings does not significantly influence the catalytic performance under the tested conditions. Taking into account the data shown in Table 1, we can conclude that gold enhances the propylene selectivity and micro-activity of the catalytic cracking reaction of light diesel oil, although it cannot simply take a subtraction of bases effect which was involved in preparation process.

The TEM observations show that the Au particles in the studied Au/ZSM-5 catalyst are predominantly distributed on the outer surface of the molecular sieve with an uneven dispersion and size. However, the embedding of a few small Au particles inside the molecular sieve pores cannot be ruled out. As evidenced by the $\mathrm{N}_{2}$ adsorption-desorption measurement, three samples with $0.5,0.8$, and $1.0 \mathrm{wt} \%$ Au loadings, which have narrower pore size distribution than the parent ZSM-5, exhibit an enhancement in both propylene selectivity and micro-activity.

According to the literature, there are two processes involved in the formation of propylene: $\beta$-scission and a proteolysis mechanism on the acid sites of the zeolite [36]. Generally, the metal sites affect the second forming carbenium species that can produce light olefins on Brønsted acid sites. Therefore, the Brønsted acid sites are very important for the catalytic cracking reaction. However, reports about how to increase the number of Brønsted acid sites of ZSM- 5 by metal modification to promote light olefins production are rare [37].

The $\mathrm{NH}_{3}$-TPD results showed that Au modification of ZSM-5 resulted in more acid sites than in ZSM-5 itself after the process of high temperature steam treatment, indicating that gold suppressed the de-alumination to some extent. Although the $\mathrm{Au}$ particles dispersed randomly on the ZSM- 5 substrate, some of the $\mathrm{Au}$ particles strongly interacted with ZSM-5 substrate by forming a flat shape. This may lead to a partial electron transfer from metallic Au to $(\mathrm{SiAl}) \mathrm{O}(\mathrm{OH})_{m}$, increasing the mobility of the proton in the hydroxyl groups and thus enhancing the acid intensity. The electron transfer will benefit the carbenium ion mechanism. In addition, the Au/ZSM-5 sample has stronger total weak acid sites (LT region). The stronger acid sites give the carbenium ions a longer lifetime to undergo secondary transformations [38].
For the catalytic cracking reaction, acid catalysis is dominant. Further research is needed to confirm the above conclusions and gain a better understand of the role of nanogold in such harsh reaction conditions.

\section{Conclusions}

The catalytic cracking reaction of light diesel over ZSM-5 with or without gold modification was investigated. The use of $\mathrm{NaBH}_{4}$ in the preparation process destroys the MFI structure of the ZSM-5 substrate and results in worse catalytic performance. Gold modification enhances the propylene selectivity, although the contribution from the bases ( $\mathrm{KOH}$ and ammonia) used during the preparation cannot be neglected. The simultaneous enhancement of the propylene selectivity and microactivity index is only obtained over the Au/ZSM-5 catalysts that maintained their MFI structure and had small Au particles with a narrow pore size distribution, relatively mild weak acidity strength and a reasonable number of strong acid sites. These results suggest that a small amount of gold has a positive effect on the catalytic cracking of light diesel oil and increased propylene production at a lower reaction temperature of $460{ }^{\circ} \mathrm{C}$.

\section{Acknowledgments}

The authors very much appreciate Professor Zifeng Yan for the assistance in $\mathrm{NH}_{3}$-TPD measurements and the supply of the parent of ZSM-5 by the Petrochemical Research Institute, PetroChina Co. Limited.

\section{References}

[1] G. J. Hutchings, M. Brust, H. Schmidbaur, Chem. Soc. Rev., 2008, 37, 1759-1765.

[2] M. Haruta, S. Tsubota, T. Kobayashi, H. Kageyama, M. J. Genet, B. Delmon, J. Catal., 1993, 144, 175-192.

[3] C. X. Qi, J. H. Huang, S. Q. Bao, H. J. Su, T. Akita, M. Haruta, J. Catal., 2011, 281, 12-20.

[4] S. S. Li, L. Tao, Q. Zhang, Y. M. Liu, Y. Cao, Acta Phys.-Chim. Sin., 2016, 32, 61-74.

[5] H. Wang, W. B. Fan, Y. He, J. G. Wang, J. N. Kondo, T. Tatsumi, J. Catal., 2013, 299, 10-19.

[6] P. Rubio-Marques, J. C. Hernandez-Garrido, A. Leyva-Perez, A.

\section{Graphical Abstract}

Chin. J. Catal., 2016, 37: 1747-1755 doi: 10.1016/S1872-2067(16)62499-3

Catalytic cracking of light diesel over Au/ZSM-5 catalyst for increasing propylene production

Caixia Qi *, Yunxia Wang, Xiaotao Ding, Huijuan Su Yantai University

$\mathrm{Au} / \mathrm{ZSM}-5$ catalysts are tested in a harsh catalytic system, i.e., the catalytic cracking of light diesel oil for maximizing propylene production, and show potential application of Au catalysts in petroleum chemistry.

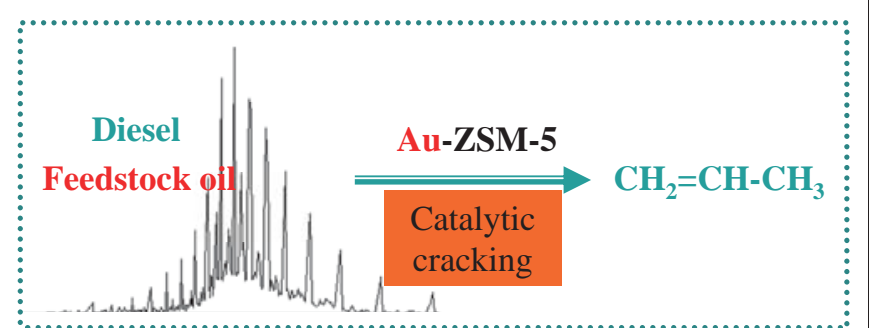


Corma, Chem. Commun., 2014, 50, 1645-1647.

[7] T. Takei, T. Akita, I. Nakamura, T. Fujitani, M. Okumura, K. Okazaki, J. Huang, T. Ishida, M. Haruta, Adv. Catal., 2012, 55, 1-124.

[8] M. Rudolph, A. S. K. Hashmi, Chem. Soc. Rev., 2012, 41, 2448-2462.

[9] X. Chen, H. Y. Zhu, J. C. Zhao, Z. F. Zheng, X. P. Gao, Angew. Chem. Int. $E d ., 2008,47,5353-5356$.

[10] A. Farshi, F. Shaiyegh, S. H. Burogerdi, A. Dehgan, Petrol. Sci. Technol., 2011, 29, 875-885.

[11] H. T. Yan, R. Le Van Mao., Appl. Catal. A, 2010, 375, 63-69

[12] Q. Shao, P. Wang, H. P. Tian, R. Y. Yao, Y. Sun, J. Long, Catal. Today, 2009, 147, 347-351.

[13] Y. Mathieu, A. Corma, M. Echard, M. Bories, Appl. Catal. A, 2014, 469, 451-465.

[14] A. Farshi, H. R. Abri, Petrol. Sci. Technol, 2012, 30, 1285-1295.

[15] P. Q. Zhang, X. W. Guo, H. C. Guo, X. S. Wang, J. Mol. Catal. A, 2007, 261, 139-146.

[16] Z. T. Xue, J. H. Ma, T. Zhang, H. X. Miao, R. F. Li, Mater. Lett., 2012, $68,1-3$.

[17] K. Hao, B. J. Shen, Y. D. Wang, J. Ren, J. Ind. Eng. Chem., 2012, 18, 1736-1740

[18] Q. Zhang, C. Y. Li, S. J. Xu, H. H. Shan, C. H. Yang, J. Porous Mater., 2013, 20, 171-176.

[19] M. A. Bari Siddique, A. M. Aitani, M. R. Saeed, S. Al-Khattaf, Top. Catal., 2010, 53, 1387-1393.

[20] N. H. Xue, X. F. Guo, W. D. Ding, Y. Chen, Chin. J. Catal., 2008, 29, 866-873.

[21] X. N. Feng, G. Y. Jiang, Z. Zhao, L. Wang, X. H. Li, A. J. Duan, J. Liu, C. M. Xu, J. S. Gao, Energy Fuels, 2010, 24, 4111-4115.

[22] X. N. Wang, Z. Zhao, C. M. Xu, A. J. Duan, L. Zhang, G. Y. Jiang, J. Rare
Earths, 2007, 25, 321-328.

[23] Z. G. Peng, G. X. Lv, Chin. J. Catal., 2007, 28, 239-245.

[24] N. Bogdanchikova, A. Simakov, E. Smolentseva, A. Pestryakov, M. H. Farias, J. A. Diaz, A. Tompos, M. Avalos, Appl. Surf. Sci., 2008, 254, 4075-4083.

[25] J. Fraissard, V. Gerda K. I. Patrylak, Y. G. Voloshyna, Catal. Today, 2007, 122, 338-340.

[26] J. N. Lin, B. Z. Wan, Appl. Catal. B, 2003, 41, 83-95.

[27] G. Riahi, D. Guillemot, M. Polisset-Thfoin, A. A. Khodadadi, J. Fraissard, Catal. Today, 2002, 72, 115-121.

[28] D. B. Akolekar, S. K. Bhargava, J. Mol. Catal. A, 2005, 236, 77-83.

[29] C. X. Qi, H. J. Su, R. G. Guan, X. F. Xu, J. Phy. Chem. C, 2012, 116, 17492-17500.

[30] C. X. Qi, S. D. Zhu, H. J. Su, H. Lin, R. G. Gua, Appl. Catal. B, 2013, 138-139, 104-112.

[31] H. C. Guo, J. X. Liu, N. L. H. Alsha, CN Patent 201310050598.0, 2013.

[32] N. L. H. Alsha, J. X. Liu, N. He, H. C. Guo, Chin. J. Catal., 2013, 34, 1262-1266.

[33] J. S. Jung, J. W. Park, G. Seo, Appl. Catal. A, 2005, 288, 149-157.

[34] A. S. Escobar, M. M. Pereira, R. D. M. Pimenta, L. Y. Lau, H. S. Cerqueira, Appl. Catal. A, 2005, 286, 196-201.

[35] G. A. Olah, A. Burrichter, G. Rasul, G. K. S. Prakagh, M. Hachoumy, J. Sommer, J. Am. Chem. Soc., 1996, 118, 10423-10428.

[36] T. F. Degnan, G. K. Chitnis, P. H. Schipper, Microporous Mesoporous Mater, 2000, 35-36, 245-252.

[37] X. F. Li, B. J. Shen, C. M. Xu, Appl. Catal. A, 2010, 375, 222-229.

[38] M. Guisnet, N. S. Gnep, D. Aittaleb, Y. J. Doyemet, Appl. Catal. A, 1992, 87, 255-270.

\title{
Au/ZSM-5 催化剂催化裂化轻柴油多产丙烯
}

\author{
祁彩霞, 王云霞, 丁孝涛, 苏慧娟 \\ 烟台大学化学化工学院, 山东省黄金工程技术研究中心 (工业应用), 山东烟台264005
}

摘要: 经过三十多年的研究与开发, 金催化已应用到环境污染治理与控制、精细化工合成和能源等领域, 涉及的化学反应 从简单的 CO 氧化和丙烯环氧化等扩展到加氢、羰化和缩合等各类有机合成反应, 研究领域从多相催化到均相催化以及光 催化等. 然而金催化所探索的反应多在较温和的反应条件下进行, 对于重油催化裂解这类高温和复杂混合反应物体系的 研究几乎无人问津. 催化裂化(FCC) 过程由于具有能耗较低、原料低廉及装置适应能力强等优点, 在增产丙烯方面发挥着 重要作用. 由于特殊孔结构的择形性、较强的酸性和低的氢转移活性以及良好的水热稳定性, ZSM-5 分子篮是目前应用于 FCC 多产丙烯催化剂和助剂最为广泛的重要组分. 值得注意的是, 目前国内外开发的改性 ZSM-5 无论是对 $\mathrm{C}_{4}$ 烃类和石 脑油等催化裂解或作为助剂用于 FCC 增产丙烯均有积极作用, 但反应温度较高 (大于 $510^{\circ} \mathrm{C}$ ); 当降低反应温度后, 其增产 丙烯的能力将受到极大限制.

本文利用纳米金低温催化活性高的特点, 采用改进的沉积沉淀 (DP) 方法, 通过调变制备参数和金载量, 制备了系列金 修饰的 ZSM-5 催化剂, 考察了其对轻柴油催化裂解多产丙烯的催化性能. 采用 X 射线衍射 (XRD)、 $\mathrm{N}_{2}$ 吸附-脱附、氨程序 升温脱附 ( $\left.\mathrm{NH}_{3}-\mathrm{TPD}\right)$ 、透射电镜 (TEM) 和诱导耦合等离子体光谱 (ICP-AES) 等手段研究了纳米金的分散状况及其对 ZSM-5 物理化学结构的调变.

结果发现, 在 $460^{\circ} \mathrm{C}$ 的较低反应温度下, 与微米 ZSM- 5 母体相比, 采用常规 DP 法制备的经过滤洗涤后未用 $\mathrm{NaBH}_{4}$ 还 原而是在 $300{ }^{\circ} \mathrm{C}$ 下空气中焙烧, 理论金载量分别为 $0.5,0.8$ 和 $1.0 \mathrm{wt} \%$ 的三个纳米金催化剂的微反活性和丙烯选择性均增 加. 其中丙烯选择性分别提高了 $8.8 \%, 2.9 \%$ 和 $23.2 \%$, 微反活性指数分别提高了 $7.1 \%, 4.3 \%$ 和 $4.5 \%$. 这表明少量金的引入 有利于在较低反应温度下催化裂化轻柴油增产丙烯, 反映了其催化裂解烃类化合物的能力.

TEM 观察表明, Au/ZSM-5 催化剂中金粒径分布非常不均匀 $(<10 \mathrm{~nm}-<200 \mathrm{~nm})$. 然而其中一些金粒子与载体呈扁平 式接触, 显示了两者间较强的相互作用. 另外一些较小的金粒子可能嵌入到狭缝片状 ZSM-5 颗粒之间的孔隙中, 这可能在 一定程度上影响了母体 ZSM-5 的孔结构分布及其催化裂化性能. XRD, $\mathrm{N}_{2}$ 吸附-脱附和 $\mathrm{NH}_{3}$-TPD 结果表明, 金引入制备 参数及其载量的变化导致了母体 ZSM-5 载体的 MFI 结构、孔结构分布及强弱酸量的变化. 上述丙烯选择性和微反活性因 
金的修饰而同时提高的三个金催化剂, 基本保持了完整的 ZSM-5 的 MFI 结构, 并且其孔分布比 ZSM-5 窄. 金的引入明显 提高了 ZSM-5 母体的酸性尤其是低温弱酸的酸强度, 然而, 综合性能优良的催化剂其强弱酸量的比例相近. 因此, 金修饰 导致微反活性和丙烯选择性的同时提高取决于改性催化剂的 MFI 结构、孔分布以及强弱酸比例的协同作用, 而金载量和 金粒子尺寸的影响不明显.

一般来讲, 修饰的金属主要通过形成正碳离子而在 B 酸位上生成轻烯烃. 高温水汽老化试验后, 金修饰的 ZSM-5 比未 修饰的ZSM-5保留了更多的酸位, 说明金在一定程度上抑制了骨架铝的脱除. 扁平状分布在母体上的金粒子与母体间较强 的相互作用可能导致部分电子从金属态金转移到 $(\mathrm{SiAl}) \mathrm{O}(\mathrm{OH})_{m}$ 上, 增加了羟基中质子的流动性而提高了改性分子䇻的酸 性, 有利于正碳离子的形成.

关键词: 催化裂化; ZSM-5；金修饰; 丙烯选择性; 微反活性测试

收稿日期: 2016-05-17. 接受日期: 2016-06-28. 出版日期: 2016-10-05.

*通讯联系人. 电话/传真: (0535)6911732; 电子信箱: qicx@ytu.edu.cn

基金来源：山东省泰山学者和烟台市双百计划; 山东省自然科学基金 (ZR2015BM006).

本文的英文电子版由Elsevier出版社在ScienceDirect上出版(http://www.sciencedirect.com/science/journal/18722067). 